Received: 8. 2. 2012.

Original scientific paper

UDK: 373.211.24.018.7-057.875

\title{
ACQUIRING METHODICAL SKILLS OF PRE- SERVICE PRESCHOOL TEACHERS: FROM ABSTRACT KNOWLEDGE TO SITUATION- BASED LEARNING ${ }^{1}$
}

Tamara Pribišev Beleslin, $\mathrm{PhD}$

Univerzitet u Banjoj Luci

Filozofski fakultet

Email: tamara.pribisev@gmail.com

Tanja Vujić

Univerzitet u Banjoj Luci

Filozofski fakultet

e-mail: a.tanja.vujic@gmail.com

\section{SUMMARY}

Students, pre-service preschool teachers, need professional competences, which include the methodical, to become autonomous professionals, empowered in their significant social role of teachers of young children, to self-express and self-realize as practitioners. Bearing that in mind, the question of the competence development and quality is becoming a significant "desirable outcome" of programs that educate future educators, including the corpus of faculty courses that make up the scientific field of Methodics of preschool education, other words, integrated methodics of early childhood education. Developing professional methodical competences of pre-service preschool teachers in higher education is not only an isolated process based on academic knowledge and teaching through lectures and academic exercises that are performed in a campus classroom environment. It is a process that is closely associate the abstract knowledge with the authentic and natural context, which, in this case, has its own continuity, soul and a lot of more things (preschool institution). It allows the meaningful construction and application of the abstract knowledge, also competence development based on experien-

1 The work with the same title was presented at II Scientific Assembly with international participance "Development and reinforcement of skills in education - priorities for faster social progress", University in East Sarajevo, Pedagogical Faculty in Bijeljina, on 18 November 2011. The book of abstracts has not been published. 
tial learning as a central concept of the postmodern adult education (Usher, 2009). Since young children about whom students learn and develop knowledge, attitudes, values, beliefs, emotions, communications skills and skills for negotiating and playing are not objects, students must be given the social situation with real children in kindergartens and real tasks from study content. In that authentic learning environments, the students will be able to understand theoretical information obtained on faculty lectures - cognitive authenticity, but also to build their professional competencies on meaning and applicability and usability manner - physical authenticity. In this regard, the paper analyses the model of faculty course Methodics of language development on the university Program study of early childhood education (Faculty of Philosophy, Banja Luka) which is still under development. Besides the theoretical basis on which model lays, paper will cover the analysis of opinions of students and their mentors - in-service preschool teachers on the effectiveness of this approach to learning in higher education institution.

Keywords: authentic learning environments, experiental learning, early childhood methodics, higher education course, model.

\section{SKILLS FRAMEWORK OF PRESCHOOL TEACHERS}

In the peek of profesionalisation and social evaluation of the profession of preschool teachers ${ }^{2}$, both on global and local level, particular attention has to be paid to development of theoretic-practical framework of the profession, that is, of the higher education framework, within which their professional skills will develop.

Modern teachers (ought to) have dynamic and reflective skills that represent a "mute“ foundation of pedagogical quality of institutional preschool education. Although it is still considered that the skills are a "property" of an individual who is responsible for them, an idea that the teacher's skills have double dimension: individual and social one (Pramling Samuelsson, Bilewu, Rabusicova, Baillargeon, Launder \& Aparecida Salmaze, 2011) is starting to form. This problematizes the question of the ability to experience an individual as the only condition and the development factor of one's skills, often in the conditions when the one who holds the power does not participate in the division of power. The teacher's personality and the skill of a person is definitely a compulsory requirement for the development of skills, however, the way the skills are formed throughout initial preparation for the profession and during long lasting working experience depends on a lot more factors, not only from the very person. If the teacher's skills are placed in the context of teams, which coincides with the program requirement to build teams as elementary functional and rational communities in preschool environment (Ministry of education and culture, 2007), then they become dependent of the organizational conditions. In that case their development is observed in the interaction between mycro, mezzo and macro system in which a professional abides. Nevertheless, in a wider perspective, one could justify the request to experience skills as a common tool, especially if

$2 \quad$ Further in text 'teacher'. 
taking into consideration that a pedagogical quality of institutional preschool education is affected by many, mutually correlated, sub-systems in a social infrastructure of which Gallanger and Clifford warn (see more in: Gallangher \& Clifford, 2000). First link in that system is education and professional preparation of future staff, where quality and organization of the system, that often need not be adjusted with the most recent trends in this field (in our case it is so), is problematized. Although higher education programs ought to be based on actual, mutually intertwined requirements of the practice and the practicians on one hand, and the theory and the theoreticians on the other hand, they are usually built based on the requirements of those who provide them, often with out of date contents that are contradictory with current practice and theory. This certainly complicates for an individual, future teacher, building of contemporary skills necessary for future work.

In aceademic circle there are no disagreements regarding the necessity and significance of preparation of future and current staff as a foundation for high quality institutions for preschool children. However, the problem is more present in the way it is carried out: division by disciplines, inability to follow new trends in education of teachers, ad hoc programs, correlation between clearer social goals, as well as of a significant involvement of teachers themselves in the process. This leads to the necessity that all persons who are involved in preparation and training of preschool staff have to have a mutual arrangement, dialogue and concensus concerning what is in fact necessary and how to respond to it.

Teachers that „know how“ to work, develop skills which become a bridge between the curriculum (social expectations) and the child (personal opinions, expectations, potentials, needs). The best and the most successful preschool program is the one which succeds in reaching a high level pedagogical quality, which balances between adult guidance and cooperative playlike learning and child initiative. Therefore, skilfull teachers, create and organize abundant and diverse situations, with a good balance between the activities initiatied by adults and by children, which are a support and a challenge for the children. The contemporary view of teacher's skills enlighten their new dimension: children and teachers play and learn (playful learning teachers and playful learning child) in a game which is fun, for enjoyment, free, internally motivated, beyond reality since it uses fantasy and creativity, in which all belong and participate, and where a child has a lot of influence (Pramling Samuelsson et al., 2011).

The globalisation and networking society era, based on a society of knowledge and respect of children rights as a planetary good, is going back to the needs for a developed and strong preschool education, which is reexperiencing its' bloom and discourse of a „smart investment" half a decade after. In such global conditions, teacher skills which come first in the lifelong learning chain, are becoming more important on „planetary level“ as well.

Overlapping and coordination of these dimensions create a skillful teacher an autonomous professional, strengthened in his/her significant social role, capable to self-express and self-realize as a practicianer. 


\section{PROFESSIONAL METHODICAL SKILLS}

There is a usual division of skills in three dimensions in literature: knowledge, skills and attitudes and beliefs. In this way the skills in the proffesion of an educator (in a wider context of a person whose profession is eduaction, where we include professors, teachers and preschool teachers), although with certain boudaries and obstacles, are defined as a „functional unity of specific knowledges, skills, attitudes and beliefs based on psycho-physical abilities and personality characteristics of a teacher" (Branković and Partalo, 2011, p. 42).

In the first wave of construction of the "educational worker" profession which started in 1960s in Latin America, Japan, OECD countries (Villegas-Reimers, 2003, p. 33), which has also included our region, a point of view that a "worker" can and should be trained for his/her work has been developed. In the era of domination of "educational workers" the caretakers ${ }^{3}$ become "preschool teachers" for whom a process of initial professional training can start to be organized. Along with this process is developed a need to systemize skills necessary for the profession (according to: Villegas-Reimers, 2003, p. 39). Up to date, knowledges (general pedagogical, methodical, knowledges from different fields, knowledges of the child context, knowledge of metaphors, stereotypes, collective beliefs, which help to correlate theory and practice, teaching skills and knowledges, evaluations; knowledges and attitudes related to inclusion field; knowledges for application of technologies) are dominant when determining these skills.

Traditionally, other dimensions of skills as results of a learning process are outstanding (Illers; 2006) although contemporary neuro sciences indicate them as equally important in that process. These dimensions are the acitvity dimensions, that is, action and affection, connotational, motivational activities which have not been considered up to now during determination of skills (Scheme 1). Love and internal bliss of an educator is not present, even though the set of this skills does not exclude its' presence. In other words, still "contemporary world represents the intelectualism era“ (Štajner, 2001, p. 11), and the descriptions of a skillful teacher are displayed with an accurate, rationally-positively constructed "educational worker" model - a person capable to transfer or upgrade knowledge.

The complexity of preschool teacher profession requires consideration of new dimensions of skills. Nowadays, a generally accepted point of view is that a teacher is a person who plays with children, he is much more than a conveyor of knowledge. Entering in different roles in a game, looking after physical and mental health and well-being of children, initiating childrens' learning, a preschool teacher has to „know how, „be able to" „can" and „want" in a different manner than the educational workers on other levels of an educational system.

3 Which is the most similar name of a profession which is closely related to the understanding of the work of "working with and looking after children". 
Scheme 1. Skill development framework of a „complete preschool teacher" (according to: Illers, 2006, p. 10)

\section{Meaning Ability}

Functionality

\section{Mental and bodily balance \\ Sensitivity}

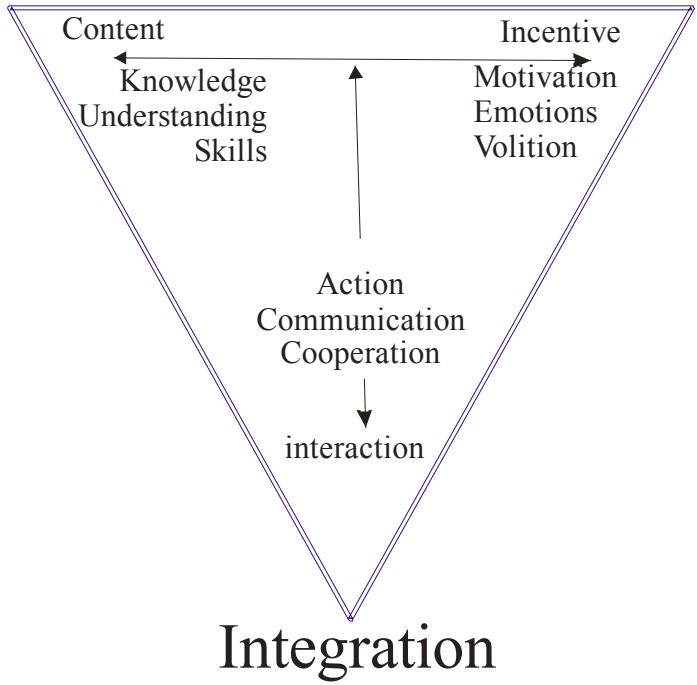

Framework for competence development of a "whole" preschool teacher(acc: Illeris, 2006, p. 10)

The first group of skills, traditionally the most developed one, according to Illers (2006, p. 10) represents a foundation for functioning of a person in a professional atmosphere. Besides the already familiar ones such as: knowledge, skills, attitudes and beliefs, it also states a number of others such as opinion, significance a person constructs of certain appearance, persons, problems, behaviour manners, acts, acting strategies and so on. It is evident that this group of skills, which gives a person a dimension of personal funcionality in micro or macro environment (of own profession) is developed through the content the person receives, builds, restructures and deconstructs during learning process in a wider context, which certainly alludes the period of professional development as well, starting with training for future profession. During studies and during the development of one's professional career, through interaction with social, society, culturological and material environment (ibid. p. 8), (future) teachers have to build definitions of their profession and abilities that will enable them to find their way and perform well in a realistic context of a preschool as a socially appreciated institution which is important for development of a community.

The second dimension of skills, encouragement, i.e. the impuls which "ignites", directs and balances mental and body energy, and which is necessary for the learning process, has up to now seldomly been correlated with professional skills. In the profession of a teacher there is one very important thing which opposes the definition in 
a positivistic sense. "Love for children" - according to some an elementary impuls of the profession, which is often present as a foundation for selection of preschool teacher vocation, is seemingly rarely operationalised as an indicator of skill. Despite the fact that in everyday meaning, that undefined love is often mentioned among students and teachers as a reason for choice of profession and the essence of the "love for the profession", it is unnatural in the context of the profession, but requires from a person an (at time indurable) emotional investment (Robin Leavitt, 1994, see also: Thornton, 2007). That personal investment can be facilitated or made harder due to social forming and personal perception of position, status and level of development of the profession of preschool teachers in a society, culture, or other professional communities. It is subject to personal perspectives, adjustable in the context of development of (professional) identity, motivation and skills. Besides the plentiful emotional investment, there is one other reqirement which describes the profession of teachers, and which is equally ambiguous and undefined making its' definition harder. "Care for well-being" of children as one of crucial commitments of teachers in a great part reiles on this dimension of skills, which require from a person "a profound involvement which leads to bonding" (Elliot, 2007), as well as building of trust and feeling of security by establishing warm relationships, mutually intertwined, within the microworld of a teaching group with, at times, even more than thirty young children. Surely, this cannot be achieved only with formed knowledge, skills and attitudes. Power of will, volition, wish, emotionality, motivation develop personal sensitivity (Illers, 2006, p. 10), and the second one is the pylon of professional skills of teachers. It should "at least" be encouraged during the process of professional forming.

The third dimension of skills, which according to Illers (2006, p. 11) gives impuls and unites the previous two is the interaction which forms a person in a social being, capable of inclusion in own (professional) community. In terms of future teachers, the interaction in the process of professional formation enables students to start their formation into a professional who works with young children by imitation, observation, transmittion, communication and sharing, activity, participation and cooperation with peers and the more experienced. As Illers points out (ibid.), only through this pillar of skills one can integrate his/her other dimensions. Action, i.e. activity, affects the transformation of a potential which a person carries and develops inside into a real "know how", "want to" and "feel how" to work with young children. Otherwise, the knowledge or how it is usually referred to the "theory" remains above, and the "practice" somewhere below!

\section{SITUATED LEARNING IN METHODICAL EDUCATION OF TEACHERS}

The development of professional methodical skills of future teachers in high level education cannot be reduced only to an isolated process based on academic knowledge and teaching by lectures and academic trainings which take place in the environment of a faculty classroom. Theoretical findings, even when accompanied by practice simulations, remain far outside of the realistic and dynamic context of a kindergarten and multidimensional interactions which take place in it on daily basis, most often unplanned. In 
that case, many dimensions of knowledge, understanding and assumptions of unity with children can be developed, although partly. Also, listening and reading about (cute) children, their learning and potentials could be a good motivational factor which, together with the "love for children", can help some students to become interested for a future profession, although that factor can at the same time act far beyond realistic abilities of the students. However, it is hardly likely that the dimensions of skills that include relationship, relations, influences, activity, communication, cooperation, playing can be developed. Nowadays, there are opinions according to which learning is indeed created inside/out of rational relationships formed between adults and children. As rational for a child as it is for an adult.

Therefore, high level education, even when preparing future explorers and scientists, and not practicianers in a field, cannot be based solely on teachings of "childless pedagogy and methodics". Learning in a realistic context is a necessity of a vocation, and it is best developed by expansion of boundaries of dominant approaches to methodical education of students future teachers.

Time spent in a kindergarten and realization of test activities (or how else can be heard: "classes") in a realistic context of an educational institution is not a novelty in organisation of higher education subjects from scientific fields of Early Childhood Education Methodics and Primary Education Methodics (out of which the former has been created by the "dilution" of content in order to adjust the forms, methods and contents for somewhat younger children prior to start of schooling). One of the tasks of such a model is to apply the knowledges one acquires on theoretical lectures and trainings in a "oneoff" practical work with a group of children or a class with pupils with whom a student often has no personal contact or established relationship. However, this outdated model of educational process, advantageous ${ }^{4}$ at that time, is not in concordance with the contemporary views of a child, education in early childhood, nor is it in concordance with the requirements that forcefully emerge out of the practice itself, especially in the curricular reform conditions (Ministry of education and culture, 2007). It can also be perilous. The changes are inevitable, the changes in multiple dimensions that require perspectives, theories and models of pedagogies, methodologies and practice in early childhood, as well as an area of high level education of future teachers.

Methodical education of future teachers (ought to be) is a process which closely connects often abstract and decontextualised (findings) knowledges with an authentic and natural context which has its' own continuity, soul and much else (preschool institutions ${ }^{5}$ ) in which their formation and application have sense. Therefore, it is inevitable to base the educational process on experience-based learning as a central concept of post-

$4 \quad$ Lave (2009, p. 202) speaks exactly about how the traditional learning theories, which many aspects of pedagogical acting were based on, were "distanced from experience".

$5 \quad$ An example from our experience tells us that during practical education students are familiarized with a wider professional context for which, at the end of the day, they are being prepared, and not only with the remote methodical field, and they are also trained to integrally react on diverse life situations. On the other hand, such mode of education enables acquirement of personal and someone elses experiences necessary for learning by different models of experience-based learning as an adequate framework of (self)education of professionals (Brankovic, 2011). 
modern education of adults (Usher, 2009).

Experienced-based learning is defined by personal perception, experience and involvement. It is a process of open possibilities and it relies on inner motivation and development, more flexible goals and learning outcomes, as well as on more flexible and more diverse ways of learning („Experiential learning“, no date). Since it includes the „interaction of internal and personal world with the external world“ (Beard-Wilson, 2006, p. 19, as cited in Branković, 2011, p. 91), but it finishes with the „transformation of experience" (Kolb, 1984, acc: ibid., p. 91), from the point of view of acquirement of professional skills of future educators, it has to be placed in the context of situated learning which is conducted by participation in "practice communities" and "context problems" (Lave, 2009, p. 200).

It is evident that the preschool children of which students learn and acquire knowledges, attitudes, convictions, emotions, communication skills, negotiation skills, playing and influences on their development and learning, are not objects. In order to enable the students to "be with them and near them" as teachers, they have to have at their disposal the social situations of children in kindergartens. Participation in practice communities, which is the foundation of the situated learning, has the exact goal to develop the feelings of belonging, understanding, development of activity and identity models that are related with those particular communities (Wenger, 2009, p. 210). In other words, presence in kindergarten (for a longer period) is essential for students in order to form a feeling of belonging in community in that particular learning atmospehere, leraning within particular relationships with other team members (teachers, expert assistants, other staff, institution management), children and their parents. By observing the educators-mentors (as „experienced peers“) and by forming realtionships with them, the students learn of their professional identity, forming slowly into experts. Thereby, they actually receive a confirmation that their future profession will be sensible and valuable for them.

In this respect, the practical education process in the methodical field does not refer only to copying teachers and transferring their models in own identity. Reflexivity and ability of critical thinking about real experiences by placing them in the context of new knowledges from a subject they are learning of (in this case methodical), represents for students the „zone of approximate development" in professional, as well as in personal sense. By gradually conquering this context guided by tasks, they have an opportunity to put to the test theoretical findings in practical situations in a realistic context, that is, in an environment which forms and affects their learning processes, experiences and outcomes with its' diverse levels (Lave, 2009).

Besides realistic situations they find themselves in, it is also important for students to have realistic tasks from the fields they study, in which and by which they will be able to have a better understanding of theoretical information they acquired in faculty - cognitive authenticity, but also to form their sense and applicability, that is, usableness - physical authenticity. It is considered to be insuffice to provide students realism in a learning environment in order to have efficient learning (see more in: A. Herrington \& J.

6 As Wenger also calls them "environments of important learning" (Wenger, 2009, p. 209). 
Herrington, 2006, p. 3). The authenticity of educational process is conducted with a natural flow of situations and interactions among students, surroundings and tasks from the teaching material context, which represent the "realistic processes of problem solving" (Smith, 1986, 1987, acc: ibid. p. 3). Such form of contextualized learning and knowledge, contrary to the decontextualised, happens exactly in the tasks which reflect the requirements from professional situations with which the students, as young experts, will have to cope with in immediate future.

In this way, the methodical education is also formed on the learning models that encompass whole student's being (emotions, imagination, conceptualization, action (Heron, 2006, p. 136)), affecting the increase of responsibility of students for the efficacy of their respective learning process. On the other hand, it is required from a teacher to base the educational process on the support principles (scaffold) and on the teaching guidance of students, as well as to move away the activation of students in the process of learning and forming of professional skills from him and his teaching procedures to the relationships between students, (as an individual and as a team member), teachers, other colleagues and himself. They are all placed in a situated „practice learning“ which, as considered by Lave (2009) is emerged in a cultural context, located in cultural-hystorical forms, interesting, conflictuous, intertwined with action, comprehension, values, rituals, styles, both individually and collectively.

Finally, the attention has to be directed to the „non-learning“ and „mislearning“ processes which both the situated and the experience-based learning can be subject to, hence so can the methodical training educational process. One of the reasons is because learning by action is an open and endless process (Lave, 2009). Therefore, it is possible to come across some indicators that point to the "non-learnng“ process (ibid.), which have to be noticed when it comes to university education. Lave specifies few of them: when learning becomes tedious and creates fatigue; when learning results with anxiety (which is regularly reproted by students) which certainly leads to the feeling of discomfort and fear in all following stays in kindergartens; if there are certain nullyfiying effects where students are not allowed access to relations between immediate and wider social context (teachers consider it is necessary to materially reward the mentorship, which gives them the right to determine whether to help students or not, show them the pedagogical documentation and so on), as well as in the cases when in the learning communities its' actors speak "different languages“ (ibid.) (e.g. the requirements placed in front of students are outside of the realistic practice context, for example, students are put in a position to ask teachers about something they cannot objectively reply to). This illustrated one more dimension of misunderstanding of theory and practice. 


\section{HIGH EDUCATION SUBJECT MODEL FROM THE CORPS OF EARLY CHILDHOOD EDUCATION METHODICS}

Although the question of modernization of methodical education is being raised more and more loudly (Spasojević and Pribišev Beleslin, 2008), it is still based on the principles of transmission of knowledge from teachers to students, and from faculty to practice.

The respective model is developed within a one semester subject Speech development methodics, in academic 2010/2011 $1^{7}$. An integral part of the curriculum, it consists of several compulsory segments:

- Theoretical classes corps (lasting for seven weeks, three classes a week),

- Introductory trainings in faculty clasrooms (lasting for five weeks, two classes a week)

- Compulsory colloquia (two times during the semester) and oral exam

- Practical classes in kindergartens with authentic tasks from the Practice book (during eight weeks, three classes a week)

- Practical classes supervision (simultaneously with the stay of students, with two hours a week)

- Taking an exam.

The program model is designed in such a way to give students the opportunities to think and assess theoretical, pedagogically-didactic and methodical, as well as practical issues related to the support for a wholesome development of a child, even though due to the nature of the subject, which is inherited, with particular focus on the development of speech and lingual activities in educational institutions, education and care of young children (from birth to start of schooling).

By participating in realistic atmosphere situation, students have possibilities to apply and expand their theoretical knowledges, as well as to practice skills and competencies of preschool children teachers. By spending time with children and teachers each week for a couple of hours continuously during two months, the students learn to play with children and develop an empathic attitude to them, and they note their needs, wishes, interests, capabilities, as well as encourage their cognition and development. In realistic situations they learn to plan, develop and apply activities and games, building up the skills of a reflexive practicianer who is able to evaluate the efficacy of planned activities. Within this model the students have a possibility to build relationships with real teachers, who become a back-bone of formation of their professional image. They are a model, a significant «other» who is worth to be imitated, followed, remembered, and for whom is worth to (fall in) love in one's future vocation.

By participating in a partly guided learning process, the students go through a process which has a spyrale from formation of theoretical knowledges, over situated learning and experience-based learning by guidance and supervision, to independent learning and acting. They plan the course of their learning in this subject which is related to formation, interpretation and systematization of theoretical and practical findings and experiences, con-

$7 \quad$ Speech Development Methodics is taught in VI semester of Study program for preschool education at the Faculty of Philosophy in Banja Luka, as a compulsory subject, which brings 5 ECTS, and lasts 3 classes and 1 classes of practices. 
necting them with the experiences they acquire from other forms of education and from within other subjects. By trying out the tasks set out in the Practice Book, the students learn different professional skills: they get to know the children and develop the ability to provide support for learning and development of a young child; they learn how to plan an educational process, documentation, playing with children, supervision of children's development and progress, ways how to organize and arrange an abundant environment for playing and learning. Besides, the program is concepted in a way to allow a student to cumulatively form experiences, knowledges, skills, relations, motifs, interests, that are necessary for preparation and execution of examination activity in an educational group, which is an integral and obligatory part of the exam from Speech development methodics. Besides, the students develop lifelong learning sklls, recognizing in themselves the professional needs that «appear», and take responsibility for own professional development and learning.

Thus concepted program model is in concordance with the characteristics of authentic learning in higher education (A. Herrington \& J. Herrington, 2006).

Scheme 2. Characteristics of authentic learning (adjusted acc. to: A. Herrington \& J. Herrington, 2006, pp. 3-9)

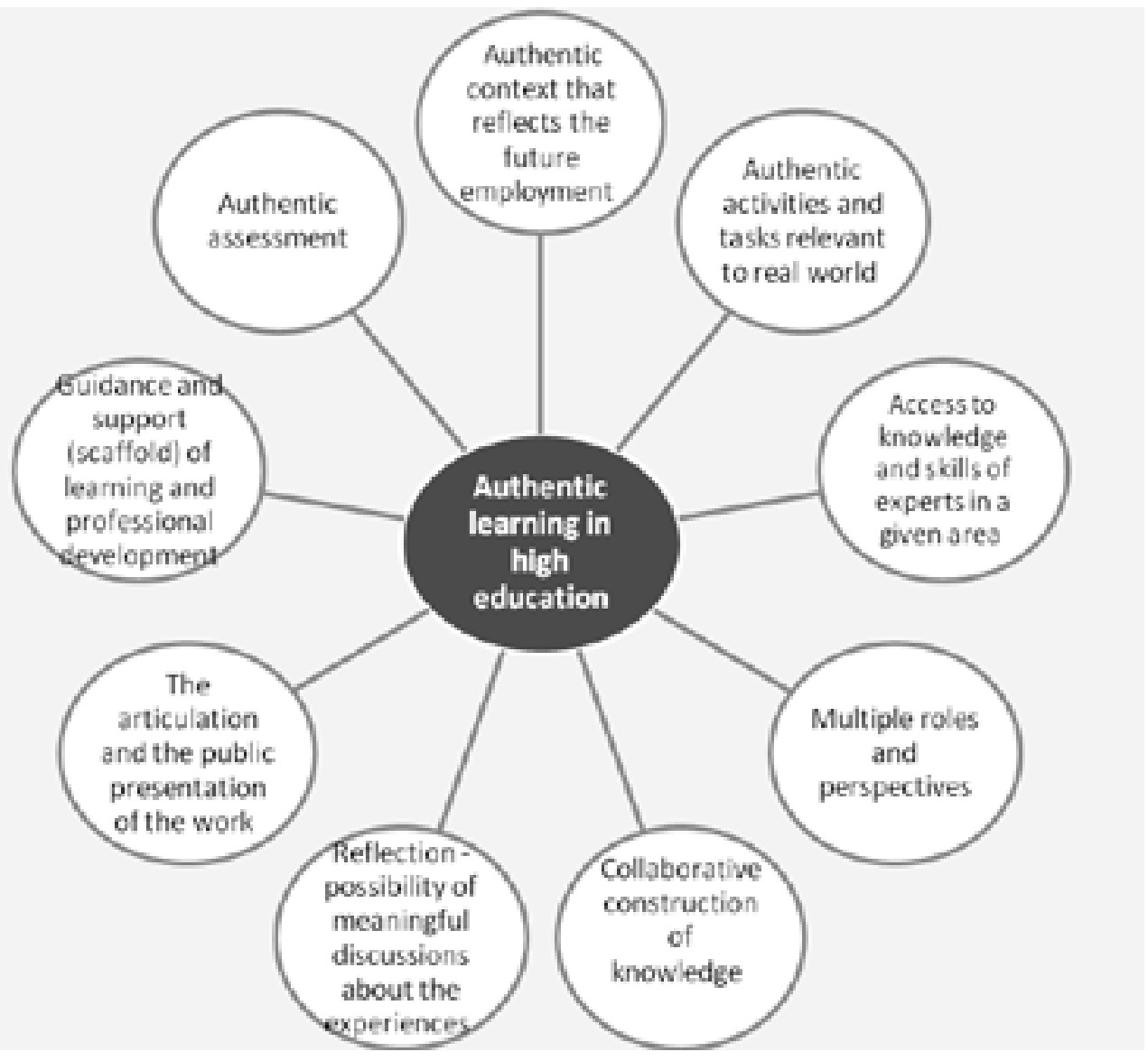


By providing the possibilities to learn in an authentic context which reflects knowledges which a teacher requires in his/her work, students form a clearer conscience of complexity of their profession and demands which will be put in front of them when they become preschool children teachers (that "theory is great, but one learns faster and more realistically from practice" is considered by one female student, whereas the other on points out that such learning mode differs from "the former mode of hospitation of preschool institutions ${ }^{(8)}$ ). They are taught in conditons which are sensible and applicable for them in the future, and probably also less subject to oblivion. Besides, authentic activities and tasks significant to the real world, as open and flexible as is the realistic context of a kindergarten, enable students to learn through work and own activity. Continuous stay in a kindergarten gives to a student a great number of opportunities to access knowledges, behaviour and skills of experts from the given area, those concrete, specific situations from kindergarten life and work, not only those prepared for students in a form of experimental activities. Multiple roles and perspectives in which students have to practice, help them to integrate knowledges from different methodical fields and faculty programs in whole. Besides, they are put in a position to accept and understand the "points of view of others" (e.g. children, teachers, who find the work extremely difficult, and often in our conditions, close to exploitation).

Reflection is given a special place within this model, regardless talking about self-reflection or reflection in a group as a mode of co-operative knowledge construction. Serious processes of exchange of knowledge occur within the educational process, but so does their sensible understanding (Branković, 2011), systematisation and forming into skills. In these terms, studetns are put in situations to observe themselves from another point of view (ibid.) by self-assessment of own experiences (feelings, motifs, procedures etc.) and by evaluation of experiences they acquire from children and teachers. That is one of the ways how to put them in a situation to, by different forms of of educational work, „overflow" and transfer their knowledges and experiences from one learning environment into another. Guidance and support (scaffold) of learning and development represent an area inside which the students learn by an organised schedule of activities, and with the support of teachers, assistants and mentors. By articulation and public presentation of respective work they have the possibility to practice and present themselves as teachers in different tasks and situations (which turned out to be one of the most stressful aspects of an educational process; e.g. performance anxiety, ,sleepless nights due to an exam, fear of failure etc.). Authentic assessment is an integral part of the process of accumulation of findings and diverse experiences, and a celebration of success in learning activities, games and communication with children, as well as the awareness of the profession which students form during the subject. 


\section{EFFICIENCY OFHIGH EDUCATION SUBJECT MODEL: SWOT ANALYSIS}

At the end of the presentation of the subject which model we have illustrated previously, we were interested to know how students and their mentors teachers ${ }^{9}$ experience this way of learning and acquirement of professional skills, and especially, how it could be improved and upgraded, having in mind their real experiences, emotions, motifs, knowledges.

\section{Participants}

41 third year student of Study program for preschool education and 14 teachers employed in the kindergartens of Banja Luka Center for Preschool Education, who have been mentors to the aforementioned students within practical lessons and supervision, participated in our research.

\section{Design}

High education subject model from the corps of early childhood education methodics is developed by spyrals of action research with active participation of teachers and assistants in it (Hitchcock \& Hughes, 2001). Having in mind that the first stage was related to the activity of students guided by teachers through a process of continuous observation, the second stage represented an area for reflection on significant issues of development of the model of a methodical subject (ethical issues in relation to students, children and teachers; student activity issues; quality of experiences, findings and outcomes of education, as well as the relations they establish with children and adults in an authentic learning environment). The scope of this stage which is presented in the paper was to reach to the understanding of difficulties and advantages which will serve for the stage of preparation of modifications and model improvements (Kemmis \& McTaggart, 2000), its' theoretical foundation ${ }^{10}$, as well as planning of the second cycle of action research on the model of methodical subject in high level education.

For the requirements of this segment of action research we have decided for SWOT analysis, and for this purpose we have created an instrument which consists of four questions which require a detailed written clarification from the participants.

The question: Which are the advantages of such way of learning and acquirement of education subject material for the students? Was answedred by all students and all teachers. The question: Which are the disadavantages or weaker sides of this way of learning and acquirement of material? Was answered by 37 students and all 14 teachers. 9 In further text instead of teacher (which in former text represented a vocation) we will use the term kindergarten teacher, having in mind that the term refers to the mentors - teachers who participated in the evaluation of the high education subject model.

10 A question of the model's foundation is particularly current in order to become adequate for the existing practice of education in early childhood, which is currently going through reform process in the direction of curricular and legal modifications and standardization, which is characterized by evident underdevelopment (e.g. coverage with institutional education is less than ten percent in $\mathrm{B} \& \mathrm{H})$. 
And finally, the last, fourth question: What could help in order to avoid the disadavantages of such way of teaching of students? Was answered by 25 students and 12 teachers.

\section{Analysis}

I QUESTION: Which are the advantages of such way of learning and acquirement of education subject material for the students?

Analysis has shown that this way of learning - learning by practice and in practice - has multiple advantages for students. Their answers were concentrated around two options which this way of learning provides. First one is that, this way, they were able to apply the learned theory in practice. Some students point out that it helped them to understand better the theory itself. A significant number of students, thereat, emphasizes that it also facilitated the learning of the given subject - Speech Development Methodics, whereas some others emphasize that, thereat, they have become more familiarized with the subject.

The second option, and at the same time the advantage of this way of learning, is that the students have had a chance to learn by personal experience in, concerning a preschool institution, authentic social situations. Students see it as a unique opportunity to acquire concrete work experience even during schooling. The above mentioned theoretical foundation of a subject itself could not provide such experience under any circumstances. The students assess that, thereby, they have had a good preparation for future employment, and one part of the students also emphasizes the fact that they have been able to grasp the actual condition and form a more realistic image of their future work. They see the advantage in direct contact with children, with real situations and problems of a kindergarten environment. They did not only observe, but they participated and experienced it as well. Some consider that this practical solution has helped them to acquire a higher level of knowledges than the theory.

One other advantage for the students is that, besides the acquirement of personal experience, they were also in a position to learn from their mentors -teachers with many years of experience.

While discussing the advantages of such way of learning, the students have not paid attention to the particularities of conducting lessons, trainings and supervision, i.e. the things that have been happening at the faculty, and which were a significant factor in the preparation of students for practice, practice analysis, and in general, in the acquirement of this subject. It seems that what had been happening in the kindergartens had the biggest and the most profound impact and significance for them, whilst neglecting the part that had happened outside of the kindergartens, at the faculty.

We also consider it important to mention that the students have given their most comprehensive answers exactly for this first question, in comparison with the other three questions. It could be concluded that the experience they had acquired in practice has left very profound and positive impressions. It was a unique opportunity because of which, speaking most generally, they are very pleased.

Teachers answered the same question in a following manner. They consider such way of learning to be positive for the students since it provides them a concrete experi- 
ence by experiencing real life situations. Here we have compliance with the students' answers. When it comes to the relation between theory and practice, the answers given by the teachers are polarised in two groups. Whereas one group consider that theory and practice supplement each other and that, in this way, the students have a better chance to better comprehend the theory and learn more, the other group considers that "theory is one, and practice is something different", and thereby, the students can acquire required knowledges and abilities to work the best in this way.

II QUESTION: Which are the disadavantages or weaker sides of this way of learning and acquirement of material?

While discussing the disadvantages, the students took into consideration those that refer to the practice which had been carried out in kindergartens, however, they also considered what had happened at the faculty as well (lectures, preparations for practice, supervision etc.). Whereas the very conduction of practice is concerned, the majority of students agree that one of the principal advantages is that the practice lasted insufficiently. Some see it as separation into pieces, the lack of continuity, since the practice had been conducted once a week, during a two month period. In kindergardens, the students also came across a difficulty because, the teachers' work plan and program, which had to be realized, was not in concordance with their commitments within the practice. They were facing difficulties with finding the opportunity, space or time to try out their tasks.

Whereas their preparation for practice, which took place at faculty and which included lectures with theoretical foundation of a subject, and thereafter also the explanations of their tasks and their ways of organization of practice, is concerned, a small number of students consider that they have been insufficiently prepared for the practice, that the tasks have not been clear enough.

A number of students, more precisely six of them, stated that such a way to learn has no disadvantages.

Teachers are in concordance with the students when they assess that the duration of practice was too short. One disadvantage they also see is that the students have more often been observers during the practice, with weak initiative, which is interpreted by some as students' lack of preknowledge. One half of the teachers stated that such a way to learn has no disadvantages.

III QUESTION: Which are the possibilities to upgrade this mode of teaching of students (from the point of view of faculty, teacher, institution-host, i.e. kindergarten, mentor and student)? While giving their explanations regarding this question, the students had some concrete suggestions. When it comes to the realization of practice, the majority of students agree it would be important to extend the duration of practice. In their opinion, it would also be good to achieve a continuity of the practice, not just within one subject or one year of studies, but to organize an integral practice, to include other subjects and all years of studies as well. The students suggest having less "observing" tasks and more practical tasks within their practice. 
Within this question, the students also discussed the very teachers as well. They consider it would be profitable if teachers were more involved in the student tasks, helping and consulting the students. The students consider the role of a teacher to be very important, and that their mutual cooperation ought to be better, more intensive and with more quality. Furthermore, it is essential to inform teachers of the tasks of the students and train them for their role in order to enable them to meet the students halfway. One student had a suggestion to enable the inclusion of teachers in the conceptualization of tasks and organization of practice. Students evaluate that it is necessary to improve the cooperation between faculties and preschool institutions.

Teachers agree that it is necessary to organize a more continuous and longer practice for the future. The student tasks were devised in a way to require their greater and more direct inclusion in the educational work in a kindergarten. One part of the teachers consider it necessary to carry out a selection of mentors in some manner, in order to select the most interested and most adequate ones for the role, with the goal of having the selection on voluntary bases and to adequately reward the mentors in a certain manner. The teachers also consider it is necessary to improve the cooperation between preschool institutions and faculties. to learn?

IV QUESTION: What could help in order to avoid the disadvantages of such way

Students have given their concrete suggestions in relation to this question as well. It would especially be desirable to introduce practice from the beginning of studies. There would also be more advantages if the teachers were more informed of their roles and tasks from the beginning.

A small number of students consider that their tasks and commitments should be explained better to them. Only one student considers that there have been too many commitments, and that their number ought to be decreased. However, a greater number of students points out that it would be better to increase the number of tasks which require a direct involvement in educational work from them, hence the practical ones, and to decrease those which put them in a position of a passive observer.

The teachers once more point out it is necessary for the students to be at practice longer and more often. Some recommend it is necessary to better prepare the students for realisation of their tasks and enable them to be involved more actively in the educational work. One teacher sets out the idea: to include mentors- teachers in the supervision at faculty.

\section{CONCLUSION}

In current spiral of our theoretical and action research, we can conclude that the model for the development of methodical competences based on situational learning in real institutional context (physical authenticity) and involving students in real processes with clearly structured tasks and problem situations (cognitive authenticity) good 
framework to support their professional growth. Having that it is an open and flexible, as a model that is suitable to adjustment in accordance with the needs of all stakeholders in it, it can be applied to the wider body of methodical "field" in earlz childhood education (as determined by the area of traditional subjects in elementary school). However, the analysis indicates that the integration of students' experiences in all areas of teaching methodics is a better and meaningfull way, given that it is often impossible to "divide" of a life in kindergarten and children's learning in the isolated areas.

Therefore, the next cycle of theoretical inquiry and action research should be directed towards the development of integrated model of students' methodical practical training, which would include and unify a variety of methodics, consequently many teachers, especially their perspectives and demands, but also compounded the activities of students and teachers, which can be related to the challenges of that integrational process. However, integrated practical training should be based on the fundamental principles set out and approved in the first cycle of action research: students and teachers learn and play (playing learning students and university teachers), professional development of student is related to support a competence of "holistic educator"; situational, contextual learning includes a good relationship between guided and independent students' learning within meaningful content to students, but that does not disturb the daily living experiences and routines of children and teachers in kindergartens; constant openness toward those processes that can be defined as "non-learning" and "mislearning." Finally, it is important to point out that this kind of engagement requires from an university teacher reflection and continuous monitoring of all signals coming from the students, preschool teachers, children and other colleagues involved in the integrated methodical education of future teachers.

Having in mind the recent findings from crucial and tangential fields it is based on, a reconstruction based on contemporary theories and approaches is neccessity ("methodics based on neuro-sciences" as the new version of "methodics of stimulation"). In in some elements a redefinition and/or development of new perspectives of a child, growing up, guided activity, profession and institutions, as well as the way of treatment of children in them ("situated methodics", "listening to children methodics", "relations methodics", "integrated methodics", "methodics of play", "third teacher' methodics" etc.) are impending to the Early Childhood Education Methodics.

The model we presented gives one framework for overcoming the socially and academically constructed gap between "theory" and "practice" in pedagogy and education, education and care in early childhood witch is most often strongly pointed out in the field of applied scientific disciplines where the Early Childhood Education Methodics certainly belongs. By its' differentiation in a particular scientific field within pedagogical sciences, it obtains its' theoretical status and clear empirical foundation set in early childhood, which, at times, has not been the case in its' history. It often represented just a "diluted" version of well developed methodics of Primary school education, with added "playing" as a well known cure for any preschool illness!

Sure directions of its' development are: clear conscience of existence of perspectives which the theory of pedagogy in early childhood is based on, with more and more 
growing need for the respect of children's point of view, created as a reflection of children rights: dialogue and "mutual sharing" between "theory" and "practice", more enlightment of the academic community in sense of respective scientific-research and professional contribution to formation of the scientific discipline "from the bottom to the top", and inducing the need to base the practice on a continuous process of (self)reflection of all its' participants.

\section{BIBLIOGRAPHY}

1. American Psychological Association (APA). (2010). Publication manual of the APA. (6th ed.). Washington, Dc: APA.

2. Branković, D. i Partalo, D. (2011). Methodological problems of defining and empirical researching of teacher competences. In K. Špijunović (Ed.), Proceeding of Scientific conference 'Instruction and learning / state and problems' (pp. 39 -50). Užice, Srbija: Teachers Faculty in Užice. 11st November, Užice.

3. Branković, D. (2011). Theory and models of experiential learning. Radovi, 14, 89 111.

4. Elliot, E. (2007). We're Not Robots. The Voices of Daycare Providers. [Adobe Digital Editions Version]. Albany, NY: State University of New York Press. Retrived from: www.gigapedia.com/

5. Experiential learning: experience-based learning - guide to facilitating effective experiential learning activities. (No date). Retrived from: www.businessballs.com/experiential_learning.htm

6. Gallangher, J. \& Clifford, R. (2000, Spring). The missing support infrastructure in early childhood. Early Childhood Research and Practice, 2(1). Retrived from: http:// ecrp.uiuc.edu/v2n1/gallagher.html

7. Herrington, A. \& Herrington, J. (2006). Authentic learning environments in higher education. Hershey - London - Melbourne - Singapore: Information Science Publishing. ISBN 1-59140-596-3 [ebook]. Retrived from: www.gigapedia.com/

8. Heron, J. (2006). Life cycles and learning cycles. In K. Illers (Eds.), Contemporary theories of learning: learning theorists-in their own words (1st Eds., pp. 129-146). London - New York: Routledge. Taylor \& Francis e-Library. ISBN 0-203-87042-5 [Master e-book]. Retrived from: www.gigapedia.com/

9. Hitchcock, G. \& Hughes, D. (1995; 2001). Research and the teacher. A qualitative introduction to school-based research. London and New York: Routledge / Falmer.

10. Illers, K. (2009). Contemporary theories of learning: learning theorists-in their own words. (1st Ed.). London - New York: Routledge. Taylor \& Francis e-Library. ISBN 0-203-87042-5 [Master e-book]. Retrived from: www.gigapedia.com/

11. Lave, J. (2009). The practice of learning. In K. Illers (Eds.), Contemporary theories of learning: learning theorists-in their own words (1st ed., pp. 200-208). London - New York: Routledge. Taylor \& Francis e-Library. ISBN 0-203-87042-5 [Master e-book]. Retrived from: www.gigapedia.com/ 
12. Ministry of Education and Culture of Republic of Srpska. (2007). Early childhood education and up-bringing curriculum. Istočno Sarajevo, Bosna I hercegovina: Zavod za udžbenike i nastavna sredstva.

13. Organisation for Economic Co-operation and Development (OECD). (2006). Starting strong II. Early childhood education and care. Paris: OECD Publication. Retrived from: www.gigapedia.com/

14. Pramling Samuelsson, I., O Bilewu, V., Rabusicova, M., Baillargeon, M., Launder, D., \& Aparecida Salmaze, M. (2011). OMEP Presidential Forum, Prominent pedagogical approaches. In Abstract book of the $63^{\text {rd }}$ OMEP World Conference: Meeting the learning and developmental needs of our young citizens (pp. 71 - 72). Hong Kong, PR China: The Hong Kong Institute of Education.

15. Kemmis, S. \& McTaggart, R. (2000). Participatory action research. In N.K. Denzin \& Y.S. Lincoln (Eds.), Qualitative research (2nd ed., pp. 567-606). Thousand Oaks London - New Delhi: Sage Publication.

16. Thornton, C. (2007). Feminism in early childhood education. In R. S. New and M. Cochran (Eds.), Early childhood education: An international encyclopedia (Vols. 1-4, pp. 366-368). Westport - Connecticut - London: Praeger. Retrived from: www. gigapedia.com/

17. Spasojević, P. i Pribišev Beleslin, T. (2008). Early childhood education and up-bringing program program in Republic of Srpska as the challenge for general metodical education of future preschool teachers. In Proceeding from International professional and scientific Conference: Educational process in preschool. Subotica, Srbija: High School for preschool teachers education. 16th-17th May 2008 Subotica.

18. Štajner, R. (2001). Aspects of Waldorf pedagogy. Annex for antroposophicaleducational practice. Zrenjanin, Srbija: Atelje Forsa. Retrived from: http://www.scribd. com/doc/27530067/Rudolf-Steiner-Aspekti-Valdorfske-Pedagogije

19. Usher, R. (2009). Experience, pedagogy, and social practices. In K. Illers (Eds.), Contemporary theories of learning: learning theorists-in their own words (1st ed., pp. 169 - 183). London - New York: Routledge. Taylor \& Francis e-Library. ISBN 0-20387042-5 [Master e-book].

20. Villegas-Reimers, E. (2003). Teacher professional development: An international review of the literature. Paris, France: UNESCO. International Institute for Educational Planning. Retrived from: www.unesco.org/iiep

21. Wenger, E. (2009). A social theory of learning. In K. Illers (Ur.), Contemporary theories of learning: learning theorists-in their own words (1st ed.,pp 209-218). London - New York: Routledge. Taylor \& Francis e-Library. ISBN 0-203-87042-5 [Master e-book]. Retrived from: www.unesco.org/iiep 